\title{
Characterization of regulatory mutations causing anaerobic derepression of the sodA gene in Escherichia coli K12: cooperation between cis- and trans-acting regulatory loci
}

\author{
MARK D. BeAumont ${ }^{3}$ and HoSNI M. HASSAN ${ }^{1,2,3 *}$ \\ Departments of Biochemistry ${ }^{1}$, Microbiology ${ }^{2}$ and Food Science, ${ }^{3}$ North Carolina State University, Raleigh, \\ NC 27695-7622, USA
}

(Received 6 April 1993; revised 14 June 1993; accepted 22 June 1993)

\begin{abstract}
The genetic loci leading to anaerobic derepression of a sod $A$ : : lac $Z$ protein fusion in a $\mathrm{UV}$-generated mutant strain (UV14) of Escherichia coli were identified. The mutant (UV14) was found to harbour two altered loci: one is in the trans-regulatory gene $f n r$ (fumarate nitrate reduction) where leucine-129 was changed to glutamine (fnr14), and the second (sodA14) is in the promoter region (cis) of the sodA gene apparently affecting the binding of the Fur (ferric uptake regulation) protein. Introduction of an $\mathrm{fnr}^{+}$gene into UV14 restored anaerobic repression of sodA ::lacZ and restored the ability of the cells to reduce nitrate. However, when either the fnr14 or the sodA14 mutation was introduced into an otherwise wild-type background, only slight anaerobic derepression of sodA was observed. When both the cis- and trans-acting mutations (i.e. sodA14 and frr14) were combined simultaneously in an otherwise wild-type background, the specific activity of $\operatorname{sod} A$ :: lac $Z$ expression was comparable to that of the original mutant strain (UV14). Furthermore, a genetically confirmed fur fnr double mutant was also similarly derepressed in anaerobic sodA ::lac $Z$ expression. The data presented suggest that the cis-mutation in UV14 (sodA14) affects the Fur-binding site in the sodA promoter, while having no effect on Fnr or Arc mediated repression. Also, a second putative Fnr-binding site that straddles the ribosomal binding-site was identified in the sodA gene.
\end{abstract}

\section{Introduction}

Catalytic removal of the superoxide radical $\left(\mathrm{O}_{2}^{-}\right)$, the first product in the univalent pathway for oxygen reduction, is accomplished by superoxide dismutases (EC 1.15.1.1; SODs) (McCord \& Fridovich, 1969). These metalloenzymes dismute superoxide to $\mathrm{H}_{2} \mathrm{O}_{2}$ and $\mathrm{O}_{2}$, therefore providing the first line of protection against oxygen toxicity (McCord \& Fridovich, 1969; Hassan, 1989). In the facultatively aerobic micro-organism Escherichia coli, three forms of SOD are found (Hassan, 1989): a constitutive iron-containing isozyme (FeSOD), an inducible manganese-containing enzyme (MnSOD), and a hybrid form composed of subunits from both the Mnand FeSODs. MnSOD is encoded by the sodA gene which is mapped at 88 minutes on the $E$. coli chromosome (Touati, 1983; Bachmann, 1990).

Conditions known to induce $\operatorname{sod} A$ include: presence of

*Author for correspondence. Tel. +1919 5156663; fax +1919515 2047; e-mail, HMHassan @ BCHSERVER.BCH.NCSU.EDU.

Abbreviation: SOD, superoxide dismutase. oxygen (Gregory \& Fridovich, 1973), changes in cellular redox potential (Schiavone \& Hassan, 1988), the addition of iron chelators (Hassan \& Moody, 1984; Moody \& Hassan, 1984; Pugh \& Fridovich, 1985), increased intracellular flux of $\mathrm{O}_{2}^{-}$by the presence of redox cycling compounds (Hassan \& Fridovich, 1977, 1979) and depletion of cellular reduced glutathione (Gardner \& Fridovich, 1987). Studies with a $\operatorname{sodA}:$ :lacZ protein fusion (Touati, 1988) have confirmed previous conclusions that $\operatorname{sod} A$ is transcriptionally regulated (Moody \& Hassan, 1984).

Moody \& Hassan (1984) proposed that transcriptional repression of $\operatorname{sod} A$ is mediated by an iron-binding redoxsensitive protein, where the putative repressor is presumed to be active when reduced iron is bound, but is inactivated under oxidizing conditions or by chelation of iron. Recent investigations have refined this model and implicated the products of several genes in the regulation of $\operatorname{sod} A$, including: the superoxide responsive regulon (soxRS; Greenberg et al., 1990; Tsaneva \& Weiss, 1990), the ferric uptake regulation gene (fur; Neiderhoffer et al., 1989, 1990; Tardat \& Touati, 1991; Beaumont \& Hassan, 
Table 1. Strains and plasmids

\begin{tabular}{|c|c|c|c|}
\hline $\begin{array}{l}\text { Strain/ } \\
\text { plasmid }\end{array}$ & Relevant genotype & Derivation & Source (reference) \\
\hline GC4468 & $\mathrm{F}^{-} \Delta l a c U 169 r p s L$ & & Touati (1988) \\
\hline QC774 & $\begin{array}{l}\text { As GC4468 but } \phi(\operatorname{sod} A:: \operatorname{lac} Z) 49 \phi(\operatorname{sodB}-K a n) \\
1-\Delta_{2} \mathrm{Cm}^{\mathrm{R}} \mathrm{Kn}^{\mathrm{R}}\end{array}$ & & Touati (1988) \\
\hline NC3 & As GC4468 but (sodA-lacZ) $49 \mathrm{Cm}^{\mathrm{R}} \mathrm{Lac}^{+}$ & & This laboratory \\
\hline NC53 & As NC3 but (sodB-Kan) $1-\Delta_{2} \mathrm{Cm}^{\mathrm{R}} \mathrm{Km}^{\mathrm{R}}$ & & This laboratory \\
\hline UV14 & As NC53 but $\mathrm{Lac}^{+}$anaerobically & & H. M. Hassan \\
\hline UV16 & As NC53 but $\mathrm{Lac}^{+}$anaerobically & & H. M. Hassan \\
\hline NC147 & As UV14, but $\operatorname{sod} A^{+}-\mathrm{Tn} 10$ nearby & & D. Touati \\
\hline NC210 & CAG5053 KL208, zbc3105:: Tn 10 & & Singer et al. (1989) \\
\hline NC211 & CAG5054 KL96, $\operatorname{trpB83::\mathrm {Tn}10}$ & & Singer et al. (1989) \\
\hline $\mathrm{NC} 212$ & CAG5055 KL16, zed3069::Tn10 & & Singer et al. (1989) \\
\hline NC400 & ECL512, fnr-1, zci::Tn10 & & Iuchi et al. (1989) \\
\hline NC402 & ECL594, arcB1 zgi::Tn10 & & Iuchi et al. (1989) \\
\hline NC411 & As NC3, but $f n r-1$ & $\mathrm{P} 1(\mathrm{NC} 400) \times \mathrm{NC} 3$ & Hassan \& Sun (1992) \\
\hline NC439 & As NC3, but fur:: Tn5 & $\mathrm{P} 1(728) \times \mathrm{NC} 3$ & Hassan \& Sun (1992) \\
\hline NC504 & As GC4468, but $\Delta f n r$ & $\begin{array}{l}\mathrm{P} 1(\mathrm{NC} 400) \times \mathrm{GC} 4468 \\
\text { then } \operatorname{Tn} 10 \text { cured }\end{array}$ & $\begin{array}{l}\text { H. M. Hassan \& H. C. H. } \\
\text { Sun }\end{array}$ \\
\hline NC506 & As GC4468, but $\Delta a r c B$ & $\begin{array}{l}\mathrm{P} 1(\mathrm{NC} 402) \times \mathrm{GC} 4468 \\
\text { cured for } \operatorname{Tn} 10\end{array}$ & $\begin{array}{l}\text { H. M. Hassan \& H. C. H. } \\
\text { Sun }\end{array}$ \\
\hline NC511 & $\mathrm{Km}^{\mathrm{R}}$ fur::Tn 5 & P1(NC728) × GC4468 & $\begin{array}{l}\text { H. M. Hassan \& H. C. H. } \\
\text { Sun }\end{array}$ \\
\hline NC600 & W3110 $\Delta l a c U 169$ tna2 & & Bagg \& Neilands (1987) \\
\hline NC658 & $\mathrm{Cm}^{\mathrm{R}}(\operatorname{sodA14}:: \operatorname{lac} Z)$ & P1(UV14) $\times$ GC4468 & This study \\
\hline NC667 & $f n r^{+} z c i:: \operatorname{Tn} 10$ & $\begin{array}{l}\mathrm{P} 1(\mathrm{NC} 400) \times \mathrm{GC} 4468 \\
\text { select for } \mathrm{Tet}^{\mathrm{R}} / \mathrm{NR}^{+*}\end{array}$ & This study \\
\hline NC672 & $\mathrm{UV14} \operatorname{sod} A^{+} \mathrm{Cm}^{\mathrm{s}}$ & $\begin{array}{l}\mathrm{P} 1(\mathrm{NC147}) \times \mathrm{UV} 14 \\
\text { select } \mathrm{Cm}^{\mathrm{s}} \mathrm{lac}^{-}\end{array}$ & This study \\
\hline NC675 & UV14 zci::Tn10 fnr ${ }^{+}$ & $\begin{array}{l}\mathrm{P} 1(\mathrm{NC} 667) \times \mathrm{UV} 14 \\
\text { select Tet }{ }^{\mathrm{R}} \text { and NR }\end{array}$ & This study \\
\hline NC676 & NC675 but nitrate reductase ${ }^{-}($fnrl4) & $\begin{array}{l}\mathrm{P} 1(\mathrm{NC} 667) \times \mathrm{UV} 14 \\
\text { select } \mathrm{Tet}^{\mathrm{R}} \text { and } \mathrm{NR}^{-*}\end{array}$ & This study \\
\hline NC677 & UV14 (sodA::lacZ)-wt & $\mathrm{P} 1(\mathrm{NC} 3) \times \mathrm{NC672}$ & This study \\
\hline NC685 & $\Delta f n r \operatorname{sod} A 14$ & P1(UV14) $\times$ NC504 & This study \\
\hline NC690 & fur sodA14 & P1(UV14) $\times$ NC511 & This study \\
\hline NC691 & $\triangle a r c B$ sodA14 & P1(UV14) $\times$ NC506 & This study \\
\hline NC696 & GC4468 sodA14/fnrl4 zci::Tn10 & $\mathrm{P} 1(\mathrm{NC676}) \times \mathrm{NC658}$ & This study \\
\hline NC701 & as NC696, independent isolate & $\mathrm{P} 1(\mathrm{NC676}) \times \mathrm{NC658}$ & This study \\
\hline NC704 & as NC729, but fnr-1 & $\mathrm{P} 1(\mathrm{NC} 411) \times \mathrm{NC} 729$ & This study \\
\hline NC707 & as NC727 but $f n r-1$ & $\mathrm{P} 1(\mathrm{NC} 411) \times \mathrm{NC727}$ & This study \\
\hline NC727 & as $\mathrm{NC600}$ but $\operatorname{sod} A:: \operatorname{lac} Z$ & P1(NC3) $\times$ NC600 & This study \\
\hline NC728 & as NC600 but fur:: $\operatorname{Tn} 5$ & & Bagg \& Neilands (1987) \\
\hline NC729 & fur:: $\operatorname{Tn} 5 \operatorname{sod} A:: \operatorname{lac} Z$ & $\mathrm{P} 1(\mathrm{NC} 3) \times \mathrm{NC7} 28$ & This study \\
\hline $\begin{array}{l}\mathrm{pDT} 1.5 \\
\mathrm{p}^{+} F n r+\end{array}$ & $\begin{array}{l}\text { sod } A^{+} \text {plasmid } \\
\text { pBR322 fnr }\end{array}$ & & $\begin{array}{l}\text { Touati (1983) } \\
\text { Jones \& Gunsalus (1983) }\end{array}$ \\
\hline
\end{tabular}

${ }^{*} \mathrm{NR}^{+}$, nitrate reductase positive anaerobically; $\mathrm{NR}^{-}$, nitrate reductase negative anaerobically.

$1990,1991,1992)$, the aerobic respiratory control (arc; Tardat \& Touati, 1991; Beaumont \& Hassan, 1991, 1992) and fumarate nitrate reduction ( $f n r$; Hassan \& Sun, 1991, 1992). Additionally, post-translational activation (Privalle et al., 1989), integration host factor (IHF; Presutti, 1992) and DNA supercoiling (Schrum \& Hassan, 1990, 1992) have been implicated in the regulation of MnSOD biosynthesis. Recently, we characterized two mutants of $E$. coli partially derepressed in the anaerobic expression of a $\operatorname{sod} A:$ : lac Z protein fusion (Beaumont \& Hassan, 1991, 1992). One of the mutants (UV16) was shown to be defective in fur and $\operatorname{arcA}$ and to be similar to another previously reported mutant (Tardat
\& Touati, 1991). The second mutant (UV14) was characterized as $\mathrm{fur}^{+}$and $\operatorname{arcA^{+}}$, yet remained partially derepressed in anaerobic expression of $\operatorname{sod} A:: \operatorname{lac} Z$ (Beaumont \& Hassan, 1992).

The present study further examines UV14, and shows that it harbours two mutations: one affecting the transacting element, Fnr, and the other affecting the cis-acting regulatory region of sodA apparently required for the binding of the trans-acting regulatory element, Fur. Either of the cis- or the trans-mutation alone confer only moderate anaerobic derepression of sodA::lacZ, while together they allow synergistic expression of $\operatorname{sod} A$ anaerobically. 


\section{Methods}

Materials. $o$-Nitrophenyl $\beta$-D-galactoside was from Sigma. The iron chelator 2,2'-dipyridyl was obtained from Aldrich. All other chemicals were of the highest quality available.

Strains and plasmids. Strains used are all derivatives of $E$. coli K12, and are listed in Table 1. Ultraviolet (UV)-generated regulatory mutants were isolated (H. M. Hassan, unpublished) based on anaerobic expression of $\beta$-galactosidase from a chromosomal $\operatorname{sod} A::$ lac $Z$ protein fusion.

Media and growth conditions. LB medium was prepared as described by Miller (1972). Where indicated the medium was supplemented with $1 \%$ glucose (LBG), and with $1 \mathrm{mM}-\mathrm{MnCl}_{2}$ when $\mathrm{MnSOD}$ was to be assayed. MacConkey agar base from Difco was supplemented with $1 \%$ lactose. Growth of the cultures was measured as optical density at $600 \mathrm{~nm}\left(\mathrm{OD}_{600}\right)$. Anaerobic growth was carried out in a Coy anaerobic chamber as previously described (Moody \& Hassan, 1984). All experiments were carried out at $37^{\circ} \mathrm{C}$.

Genetic techniques and strain construction. P1 transduction was as described by Miller (1972). Transformation and plasmid preparation followed protocols described by Sambrook et al. (1989). Mapping of the sodA trans-acting regulatory mutations was carried out by $\mathrm{Hfr}$ conjugational crosses as described by Singer et al. (1989). Marker exchange in transconjugants was observed by anaerobic $\mathrm{Lac}^{-}$phenotype (expressed from $\operatorname{sod} A:: \operatorname{lac} Z$ ) in colonies which harboured both donor $\left(\mathrm{Tet}^{\mathrm{R}}\right)$ and recipient $\left(\mathrm{Cm}^{\mathrm{R}}\right)$ markers.

Enzyme assays. $\beta$-Galactosidase was assayed as described by Miller (1972), and the data were plotted in the form of differential plots (i.e. changes in $\mathrm{U} \mathrm{ml}^{-1}$ vs. changes in $\mathrm{OD}_{600}$ ). Superoxide dismutase was assayed by the xanthine oxidase/cytochrome $c$ method of McCord \& Fridovich (1969) using cell-free extracts prepared as previously described (Moody \& Hassan, 1984). Nitrite was determined by the method of Hanson \& Phillips (1981). Enzyme assays were carried out at $25^{\circ} \mathrm{C}$ using a Kontron spectrophotometer. Protein was estimated by the Lowry method with a bovine serum albumin standard. Activity gels for resolution of active forms of SODs were carried out as described in Beauchamp \& Fridovich (1971), and quantified by an LKB Laser densitometer.

Cloning and sequencing. Total chromosomal DNA from both the wild-type (GC4468) and mutant (UV14) strains was isolated as described in Sambrook et al. (1989) and used to amplify the fnr gene by the Taq-polymerase chain reaction in a thermocycler (Precision Scientific) using 18 bp primers annealing to both the $5^{\prime}$ end (bases 180 to 197 ) and the $3^{\prime}$ end (bases 1380 to 1363 ) based on the published fnr sequence (Shaw \& Guest, 1982). Typical reaction conditions were: $10 \mathrm{ng}$ template, $1 \mu \mathrm{M}$ primers, with $94^{\circ} \mathrm{C}$ denaturation $(1 \mathrm{~min}), 54^{\circ} \mathrm{C}$ annealing $(1 \mathrm{~min})$ and $74^{\circ} \mathrm{C}$ extension $(1.5 \mathrm{~min})$. The amplified fragments were cloned and sequenced by single stranded, M13 sequencing using described protocols and reagents (USB). Dideoxy sequencing reactions (Sanger et al., 1977) were resolved on a $5 \%$ Long Ranger (AT Biochem) acrylamide gel and autoradiographed using Kodak X-omat AR film. The mutation was confirmed in two independent genomic DNA isolations and two independent PCR reactions.

\section{Results}

\section{Mapping of trans-acting regulatory loci in UV14}

The Hfr strain kit provided by C. Gross (Singer et al., 1989, and Table 1) was used to map the mutant phenotype in UV14. Conjugation between UV14 and
Hfr strains NC210, NC211 and NC212 led to conversion of UV14 to a wild-type phenotype (i.e. conversion of a $\mathrm{Lac}^{+}$to $\mathrm{Lac}^{-}$phenotype on anaerobic MacConkey agar plates) at a frequency of $62 \%, 80 \%$ and $10 \%$, respectively (representative values from two crosses). NC210 transfers a region of DNA $\left(12^{\prime} \rightarrow 35^{\prime}\right)$ that overlaps with that transferred by NC211 $\left(25^{\prime} \rightarrow 45^{\prime}\right)$ in the region between $\left(25^{\prime} \rightarrow 35^{\prime}\right)$. This overlapping region is known to include the locus for fnr located at $29.5^{\prime}$ (Bachmann, 1990), which has been recently implicated in sodA regulation (Hassan \& Sun, 1991, 1992). Therefore,

\section{Table 2. Effect of mutation(s) in UV14 on nitrate reduction}

Cells were grown anaerobically at $37^{\circ} \mathrm{C}$ in LB medium with $1 \%$ glucose (LBG) and $0.1 \% \mathrm{KNO}_{3}$. Overnight cultures were used to inoculate LBG and samples were withdrawn for determination of both $\mathrm{OD}_{600}$ and nitrite. Values are taken from the mid-exponential phase of growth.

\begin{tabular}{llc}
\hline \multicolumn{1}{c}{ Strain } & \multicolumn{1}{c}{ Phenotype } & $\begin{array}{c}\text { Nitrite } \\
{\left[\mathrm{mmol}^{\prime}\right.} \\
\left.\left(\mathrm{OD}_{600}\right)^{-1}\right]\end{array}$ \\
\hline NC53 & Wild-type Fnr & $5 \cdot 98$ \\
UV14 & sodA derepressed mutant & 0.84 \\
UV14/pFnr & sodA derepressed mutant/Fnr \\
NC675 & UV14 Fnr $^{+}$ & $3 \cdot 30$ \\
NC411 & Fnr $^{-}$ & $5 \cdot 54$ \\
NC411/pFnr & Fnr $^{+}$ & 1.05 \\
\hline
\end{tabular}

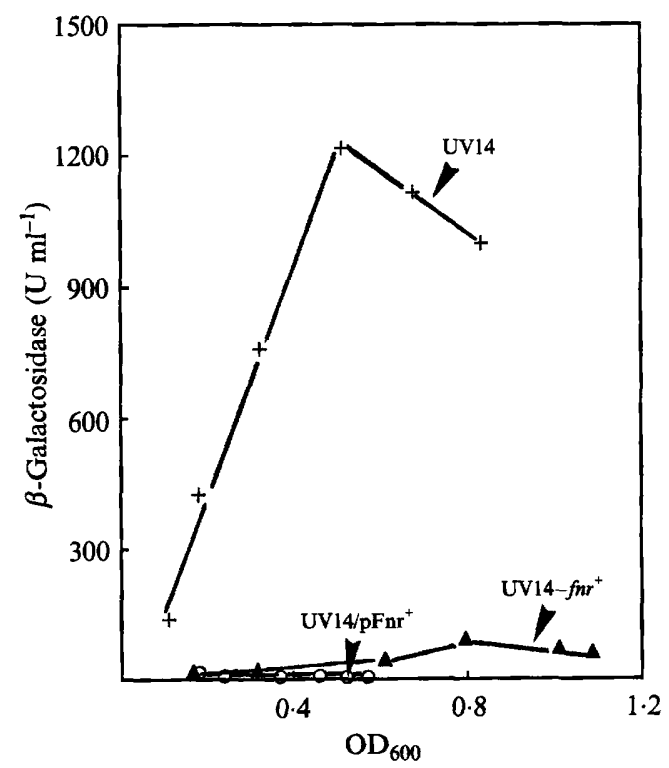

Fig. 1. Effects of the $f n r^{+}$gene on anaerobic expression of $\operatorname{sod} A:$ : lacZ in UV14. UV14 was transformed with plasmid-borne $f n r^{+}\left(\mathrm{pFnr}^{+}\right)$, or transduced with a P1 lysate from a strain carrying a $z c i:: \operatorname{Tn} 10$ marker closely linked to $\mathrm{frr}^{+}$, to give strain NC675. Culture conditions and assay procedure are as described in Table 3 and in Methods. 
(a)

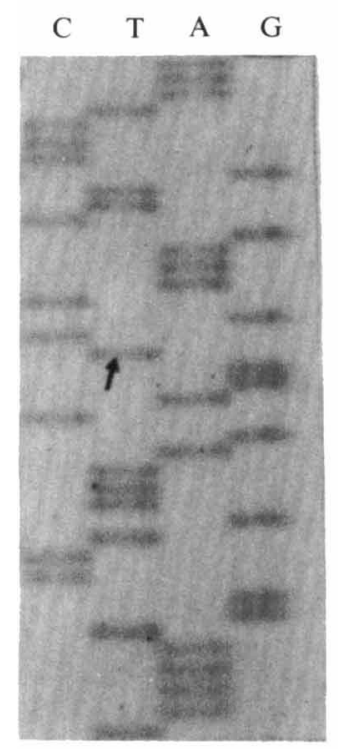

Wild-type

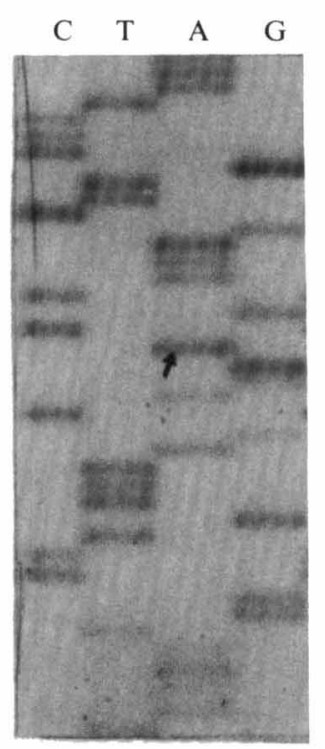

UV14 (b)

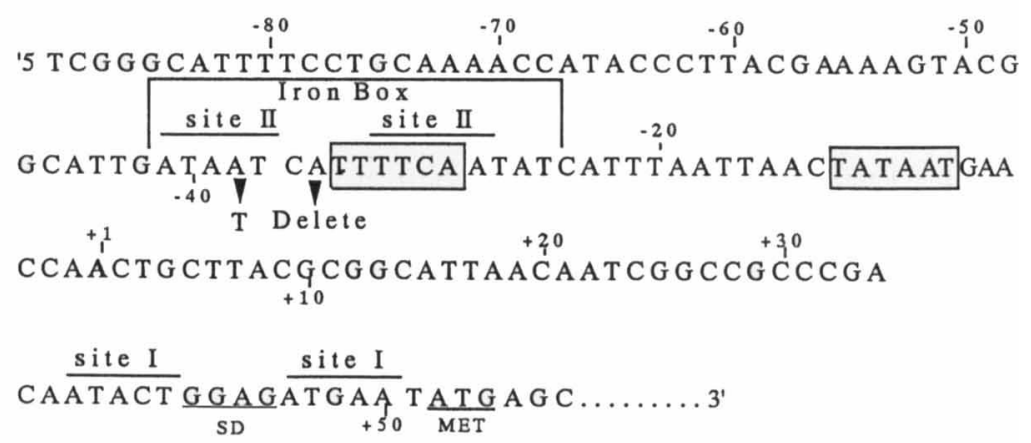

Fig. 2. (a) Autoradiogram of a sequencing gel showing the mutated region of the UV14 fnr gene and the corresponding region of the cloned and sequenced wild-type gene from GC4468. The portion of the sequence shown corresponds to bases 887 through 926 of the published sequence (Shaw \& Guest, 1982). The change of CTG to CAG (reading from top to bottom) is the mutated codon at amino acid 129, with the $T$ to A change at base 905 . (b) Upstream regulatory region of the sodA gene (Takeda \& Avila, 1986) showing the proposed Fur-binding 'iron box'; the -10 and -35 regions (boxed); the ribosomal binding-site (underlined); the two potential Fnr binding-sites (overlined; sites I and II); and the base changes (A to T and a A deletion) found in sodA14 (arrows; from S. Bowen \& H. N. Hassan, in preparation).

we explored the possibility that UV14 contains a mutation affecting the expression of Fnr.

\section{fnr mutation found in UV14}

The fnr locus has been shown to be an indispensable upregulator for the function of anaerobic respiratory systems, including nitrate reductase, fumarate reductase and DMSO/TMAO reductases (Spiro \& Guest, 1990). Data in Table 2 show that the ability of UV14 to reduce nitrate was significantly lower than that of the wild-type strain but similar to a well-defined fnr mutant (NC411) (compare lines 2 and 5, Table 2). Furthermore, the $f n r^{+}$ gene provided either by $\mathrm{P} 1$ transduction or on a multicopy plasmid led to wild-type levels of $\operatorname{sodA}:: \operatorname{lac} Z$ anaerobically (Fig. 1) and restoration of nitrite production (Table 2, lines 3 and 4).

Cloning and sequencing of the fnr gene from UV14 and its wild-type parent identified a single base change in the coding region that differed from the published sequence (Shaw \& Guest, 1982) and from the cloned wild-type gene (Fig. $2 a$ ). The single base change (T at position 905 to A) led to a leucine-129 to glutamine conversion. This mutant allele is termed fnr14. Additionally, we found that base 1316 , in the termination loop of $f n r$, was changed from a $\mathrm{T}$ to a $\mathrm{G}$ (data not shown). We also noted an error of TCG to TGC at amino acid 29 in the published $f n r$ sequence. This error has also been noted by Trageser et al. (1990) and Kiley \& Reznikoff (1991).

\section{A second mutation discovered in UV14}

The fact that mutations in the $f n r$ gene do not cause anaerobic derepression of the sodA gene (Hassan \& Sun, 1991, 1992), suggested that UV14 must also possess other mutation(s) causing the observed phenotype. Concurrently, it was discovered that UV14 harboured a cis-acting mutation which was subsequently cloned and sequenced (S. Bowen \& H. M. Hassan, unpublished; Fig. $2 b$ ). The effect of this cis-mutation (termed sodA14) on $\operatorname{sod} A$ : : lac $Z$ expression was examined in a wild-type background (Fig. $3 a$ ) (strain NC658 was constructed by transduction of GC4468 with a P1 lysate prepared on UV14 and selecting for $\mathrm{Cm}^{\mathrm{R}} / \mathrm{Lac}^{+}$aerobically). Very low levels of anaerobic $\beta$-galactosidase activity were observed in the constructed sodA14 mutant (NC658), and the addition of iron chelator did not increase the expression of $\operatorname{sod} A::$ lac $Z$; instead it decreased the level of expression for some unknown reason (Fig. 3a).

Conversely, a strain was constructed (NC672) in which the defective sodA14 locus was replaced by the 

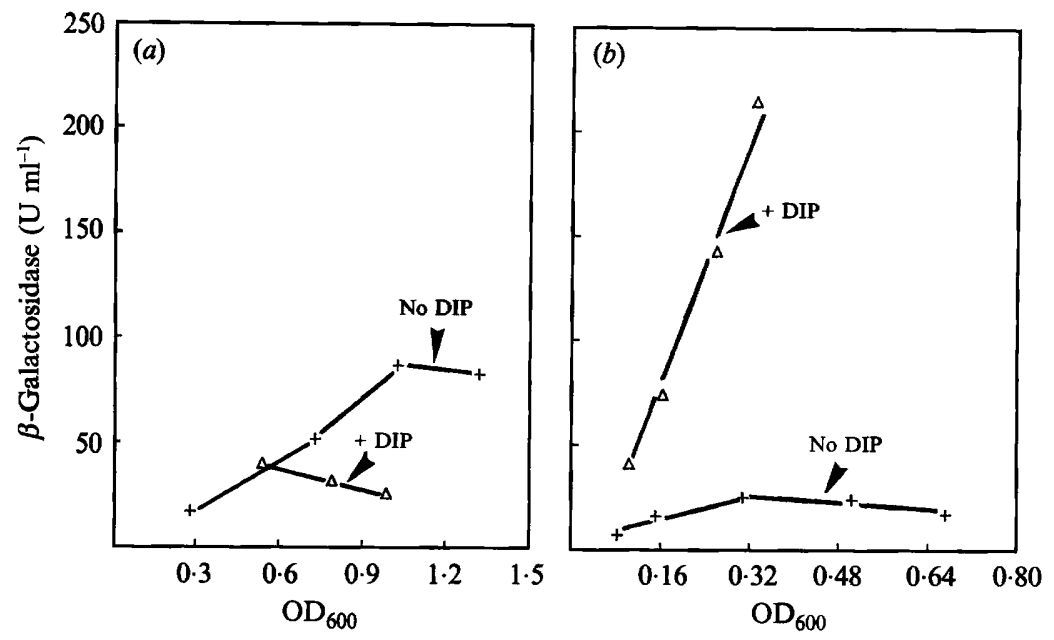

Fig. 3. Anaerobic derepression of $\operatorname{sod} A:: \operatorname{lac} Z$ due to cis-acting ( $\operatorname{sodA14}$; NC658; panel $a$ ) and trans-acting (fnr 14; NC677; panel b) mutant elements of UV14. Culture conditions, addition of the iron chelator 2,2'-dipyridyl (dip), and determination of $\beta$-galactosidase were as described in Fig. 1 and in Methods. corresponding wild-type locus to observe the effects of the trans-acting regulatory mutation from UV14 (i.e. fnr14) on sodA::lacZ expression. Again, no significant derepression of $\operatorname{sodA}:$ :lac $Z$ activity was observed, but induction by $2,2^{\prime}$-dipyridyl was restored (Fig. $3 b$; repeated three times, representative values shown).

\section{Synergistic effects of cis- and trans-mutations of UV14 on anaerobic expression of $\operatorname{sod} A::$ lac $Z$}

The lack of significant derepression of $\operatorname{sod} A$ as a result of either the sodA14 or fnr 14 mutation (Fig. 3) led us to investigate the combined effects of these two mutations in a genetically clean wild-type background. Strains were constructed (NC696 and NC701) which harboured the sodA14 along with the fnrl4 mutations. We also combined the sodA14 mutation with a confirmed fnr mutation (NC685). In all three constructed strains, the anaerobic levels of $\operatorname{sod} A:: \operatorname{lac} Z$ expression were elevated about 10- to 15-fold over the additive effects of either sodA14 or fnr 14 mutation alone (Fig. 3), and the level of expression of NC696 and NC701 was similar to that of UV14 (Table 3; representative values for three determinations shown).

\section{sodA14 Mutation prevents induction of sodA : :lacZ by iron chelation}

In order to explore the reasons for lack of induction of sodA : : lac $Z$ by $2,2^{\prime}$-dipyridyl in UV14, we examined the effect of $\operatorname{sod} A 14$ on the expression of a $\operatorname{sod} A^{+}$gene from a multicopy plasmid. Thus, the wild-type strain (NC53) and the mutant strain (UV14) were transformed with plasmid pDT1.5 (Touati, 1983; harbouring $\operatorname{sod} A^{+}$), and the effects of $2,2^{\prime}$-dipyridyl on the simultaneous anaerobic expression of $\beta$-galactosidase from the chromosomal sodA::lac $Z$ and MnSOD from the plasmid, pDT1.5, were observed. Data in Table 4 show that
Table 3. Anaerobic expression of sodA:: lac $Z$ in strains harbouring both sodA14 and fnr14 mutations from UV14

Strains were grown anaerobically at $37^{\circ} \mathrm{C}$ in LBG. Overnight cultures were used to inoculate $10 \mathrm{ml}$ cultures, from which samples were drawn at time intervals for determination of both $\mathrm{OD}_{600}$ and $\beta$-galactosidase as described in Methods.

\begin{tabular}{|c|c|c|}
\hline Strain & Genotype & $\begin{array}{c}\beta \text {-Galactosidase } \\
{\left[\mathrm{U}\left(\mathrm{OD}_{600}\right)^{-1}\right]}\end{array}$ \\
\hline NC53 & Wild-type & 5 \\
\hline UV14 & $\operatorname{sod} A$ derepressed mutant & 1603 \\
\hline NC685 & $\Delta f n r / \operatorname{sod} A 14$ & 2688 \\
\hline NC696* & fnr $14 /$ sodA14 & 1609 \\
\hline NC701* & fnr $14 / \operatorname{sod} A 14$ & 1606 \\
\hline
\end{tabular}

* Independent isolates from two separate constructions.

Table 4. Effect of 2,2'-dipyridyl on the anaerobic expression of $\operatorname{sod} A^{+} /$sod $A::$ lac $Z$ from wild-type and mutant (UV14) strains harbouring pDT1.5

Cultures were grown anaerobically in LBG at $37^{\circ} \mathrm{C}$ with $1 \mathrm{~mm}$ $\mathrm{MnCl}_{2}$. Overnight cultures were used to inoculate $50 \mathrm{ml}$ of the same medium. At time intervals, samples were withdrawn for determination of both $\mathrm{OD}_{600}$ and $\beta$-galactosidase. When cells reached mid-exponential phase, they were harvested by centrifugation and cell-free lysates prepared and assayed for MnSOD as described in Methods.

\begin{tabular}{|c|c|c|c|c|}
\hline \multirow[b]{2}{*}{ Strain } & \multicolumn{2}{|c|}{$\begin{array}{l}\mathrm{MnSOD} \\
\left(\mathrm{U} \mathrm{mg}^{-1}\right)\end{array}$} & \multicolumn{2}{|c|}{$\begin{array}{c}\beta \text {-Galactosidase } \\
{\left[\mathrm{U}\left(\mathrm{OD}_{600}\right)^{-1}\right]}\end{array}$} \\
\hline & -DIP & $+\mathrm{DIP}^{*}$ & - DIP & + DIP* \\
\hline $\mathrm{NC} 53 / \mathrm{pDT} 1.5$ & 0.4 & 33.7 & 26 & 352 \\
\hline UV14/pDT1.5 & $25 \cdot 8$ & $392 \cdot 2$ & 1321 & 1348 \\
\hline
\end{tabular}

* Where indicated, 2,2'-dipyridyl $(0.5 \mathrm{~mm})$ was added when cells reached an $\mathrm{OD}_{600}$ of about $0 \cdot 1$.

UV14/pDT1. 5 responded to chelator addition with an 11 -fold increase in MnSOD, while $\beta$-galactosidase, driven from the mutated cis-acting regulatory region 

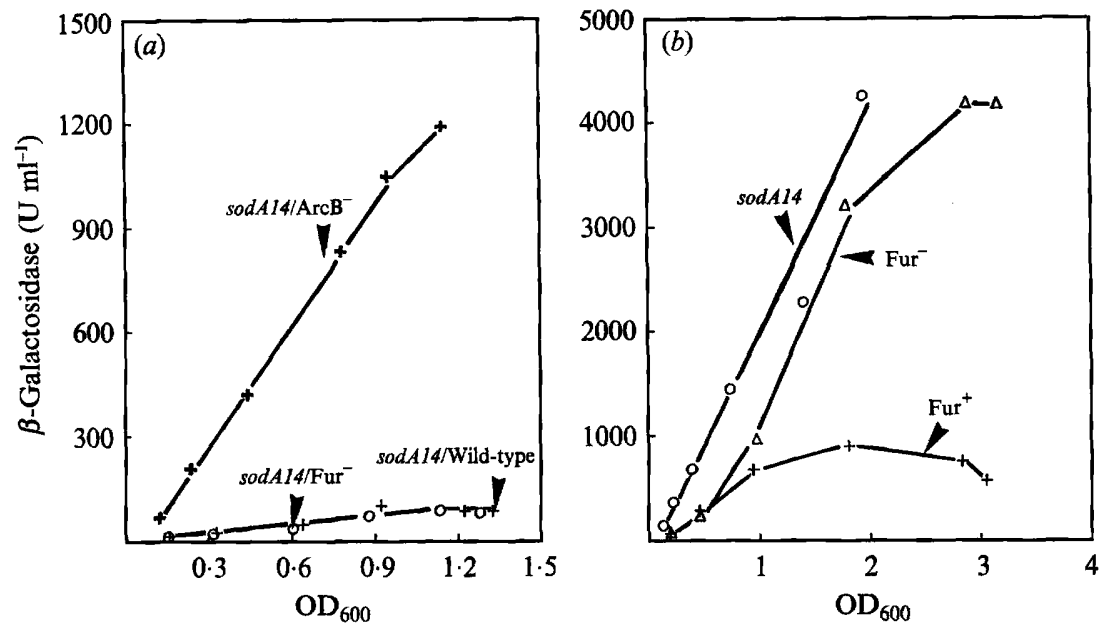

Fig. 4. Expression of $\operatorname{sod} A:$ :lac $Z$ from a strain harbouring sodA14 mimics that from a known fur mutation. (a) Combined effects of sodA14 with fur (NC690) (O), arcB (NC691) (+) or wild-type (NC658) (+) background on anaerobic expression of sodA::lacZ. (b) Effects of fur and sodA14 on aerobic expression of sodA:lacZ: $\mathrm{O}$, fur $^{-}$(NC439); $\triangle, \operatorname{sodA14}(\mathrm{NC658}) ;+$, fur $^{+}$ (NC3). Culture conditions and assay of $\beta$ galactosidase were as described in Fig. 1 and in Methods.
(sodA14), remained unchanged. In contrast, NC53/ pDT1.5 demonstrated inducibility of both the plasmidborne sodA (MnSOD) and the chromosomal sodA::lacZ (Table 4; repeated twice, representative values shown). These data show that the sodA14 mutation acts only in cis in abolishing the induction of $\operatorname{sod} A$ by iron chelation.

\section{cis Mutation in UV14 mimics fur mutation}

Because the base changes in the sodA14 mutation fell within the Fur-binding site 'iron box' of the sodA regulatory region (S. Bowen \& H. M. Hassan, unpublished; Fig. $2 b$ ), strains were constructed to assess the phenotype conferred by this mutation. If the sodA14 mutation does prevent binding of and repression by Fur protein, $\operatorname{sod} A$ ::lacZ expression in such a mutant would be similar to that previously observed in a fur mutant. Indeed, the introduction of sodAl4 into an $\mathrm{Arc}^{-}$ background (NC691) resulted in partial anaerobic derepression of $\operatorname{sod} A:: \operatorname{lac} Z$ (Fig. $4 a$ ), as would be expected from a strain lacking repression by Fur and Arc (Tardat \& Touati, 1991; Beaumont \& Hassan, 1992). Also, cells harbouring the sodA14 region demonstrated higher aerobic expression of $\operatorname{sod} A$ :: lac $Z$ (Fig. $4 b$ ), as was reported for fur mutants (Neiderhoffer et al., 1990; Tardat \& Touati, 1991; Beamont \& Hassan, 1992; Hassan \& Sun, 1992).

Strains harbouring mutations in both fur and fnr show elevated anaerobic expression of $\operatorname{sod} A::$ lac $Z$

UV14 contains two mutations; a promoter mutation which appears to effect binding of Fur to the $\operatorname{sodA}$ promoter, and a trans-mutation which disables Fnr function. It remains to be determined if the $\operatorname{sod} A$ phenotype of UV14 is a result of the combined effects of only the sodA14 and the frr 14 mutations. If so, a double trans-acting mutant (fur fnr) should phenotypically
Table 5. Anaerobic expression of sodA $A^{+}$and $\operatorname{sod} A::$ lac $Z$ in fur, fnr, and fur fnr mutant strains and effect of 2,2'dipyridyl

Isogeneic strain pairs harbouring sodA : lacZ (NC727, 707, 729, 704) were grown overnight in LBG (with $1 \mathrm{mM}-\mathrm{MnCl}_{2}$ when $\mathrm{MnSOD}$ assayed) at $37^{\circ} \mathrm{C}$. Culture conditions and assay procedures were as described in Table $\mathbf{4}$ and in Methods.

\begin{tabular}{llcc}
\hline \hline & & \multicolumn{2}{c}{$\begin{array}{c}\beta \text {-Galactosidase } \\
{\left[\mathrm{U}\left(\mathrm{OD}_{600}\right)^{-1}\right]}\end{array}$} \\
\cline { 3 - 4 } Strain & Genotype & -DIP & +DIP* \\
\hline NC727 & Wild-type & 6 & 139 \\
NC707 & fur & 37 & 366 \\
NC729 & fur & 65 & 517 \\
NC704 & fur fnr & 857 & 378 \\
\hline \hline
\end{tabular}

* The iron chelator $2,2^{\prime}$-dipyridyl was added at an $\mathrm{OD}_{600}$ of approximately $0 \cdot 1$.

behave like UV14, with respect to the anaerobic expression of sodA. The data (Table 5; representative values of two experiments) clearly show that the absence of both functional Fur and Fnr proteins resulted in anaerobic expression of $\operatorname{sodA}:: \operatorname{lac} Z$, as well as loss of induction by $2,2^{\prime}$-dipyridyl as observed in UV14.

\section{Discussion}

The mutant strain UV14 was found to harbour two mutations: one is in the $f n r$ gene and the second is in the promoter region of the $\operatorname{sod} A$ gene apparently affecting the binding of the Fur protein. A fur fnr double mutant behaved similarly to UV14, and also lacked responsiveness to iron chelation. These results are in contrast to earlier findings (Hassan \& Sun, 1992) which showed lack of anaerobic expression of $\operatorname{sod} A::$ lac Z in a fur fnr double mutant. It was subsequently found that the fur fnr strain used by Hassan \& Sun (1992) was a 'leaky' mutant with respect to the fur locus (H. M. Hassan \& H. C. H. Sun, 
unpublished); however, this was not the case for the double mutant used in the present study.

The $f n r$ mutation in UV14 was found to be a leucine to glutamine conversion at amino acid 129, and resulted in loss of a Fnr-mediated function (i.e. anaerobic nitrate reduction). The mutation does not fall within the proposed secondary structures of Fnr postulated to bind iron or DNA on Fnr-regulated genes, but falls near the nucleotide binding domain in the homologous Crp protein (Spiro \& Guest, 1990). It is interesting to note that a region of Fnr adjacent to this has been implicated in subunit association (Kiley \& Reznikoff, 1991). If the fnr 14 mutation alters the association constant of the Fnr subunit and subsequent active Fnr formation, repression of $\operatorname{sod} A$ may be affected. The ability to directly assess the in vitro binding of the Fnr protein to the sodA promoter is hampered by the difficulty in isolating a biologically active Fnr protein (Kiley \& Reznikoff, 1991).

The second mutation (Fig. $2 b$; S. Bowen \& H. M. Hassan, unpublished) falls within the proposed binding site of the Fur protein to the sodA promoter region (Neiderhoffer et al., 1989; Naik \& Hassan, 1990). This mutation resulted in moderate anaerobic derepression of $\operatorname{sod} A$, and is refractory to chelator induction. When the sodA14 and fnr 14 mutations were present together, synergistic expression of sodA was observed anaerobically (Table 3 ). The data also suggest that the sodA14 mutation does not affect the putative binding sites for Fnr and/or Arc (Table 3 and Fig. 4a). The lack of chelator enhanced expression when the sodA14 mutation is present (Fig. $3 a$; Table 4) could also be interpreted such that the mutated site might be important for the binding of an activator molecule. The ability of a strain harbouring sodA14 (NC658) to be induced by paraquat in air (data not shown) suggests that this mutation does not fall within the site required for SoxS mediated activation of sodA (Greenberg et al., 1990; Tsaneva \& Weiss, 1990).

The $f n r$ locus encodes a redox-sensitive, iron-binding protein which regulates cellular electron flow based on the level of available electron acceptors (Spiro \& Guest, 1990; Unden \& Trageser, 1991). It is postulated that the metallated protein binds to a 22 bp consensus sequence upstream of regulated genes, located near the -35 region in up-regulated genes, and close to the +1 site in repressed genes (Spiro \& Guest, 1990). It is interesting to note that, based on sequence homology to the Fnr consensus sequence, two putative Fnr-binding sites (Fig. $2 b$; sites I and II) are found in the $\operatorname{sod} A$ gene; one previously identified in the -35 region (Hassan \& Sun, 1992), and one identified in this study that straddles the ribosomal binding-site. Previous studies (Hassan \& Sun, 1992) suggested that $f n r$ might function as both a repressor and activator in $\operatorname{sod} A$ regulation. It is inter- esting to speculate on the function of these two Fnrbinding sites in the regulatory region of the $\operatorname{sod} A$ gene; thus 'site I' may serve for binding of a repressor form of Fnr (i.e. metallated Fnr) while 'site II' may allow the binding of an activator form of Fnr (i.e. demetallated Fnr). This conclusion is supported by the fact that the cis-mutation in UV14 (sodA14), which overlaps the ironbox and 'site II' (Fig. 2), was still responsive to $f n r$ mutations with respect to expression of $\operatorname{sod} A:$ :lacZ. Also, recent studies have shown that sodA mutants deleted in the iron-box and 'site II' were still induced for sod $A:$ lac $Z$ in response to a deletion in the $f n r$ gene (Compan \& Touati, 1993). Therefore, it is more likely that 'site I' is the site essential for negative regulation of $\operatorname{sod} A$ by Fnr. The presence of 'site I' in the untranslated region of $\operatorname{sod} A$ mRNA may suggest post-transcriptional regulation of $\operatorname{sod} A$ by Fnr. Work is in progress to further examine this possibility.

The synthesis of these data into a comprehensive model will require further studies into the mode of action of the multiple elements implicated in sodA regulation. Perhaps most important will be sorting true repressor/ activator elements from pleiotropic effectors which only modify cellular physiology, and hence activity of the true effector(s). However, present and previous findings clearly indicate that mutational loss of Fur function (i.e. as in fur or sodA14) in combination with a second mutation in either $f n r$ or arc is necessary for partial anaerobic derepression of $\operatorname{sod} A$, while full derepression requires the simultaneous inactivation of all three repressors (Fur, Arc and Fnr) (Hassan \& Sun, 1992; Compan \& Touati, 1993). Recent studies have suggested a functional or physical linkage between Arc and Fnr proteins in regulatory processes (Sawers \& Suppman, 1992). However, in the absence of direct evidence for Fnr or Arc binding to $\operatorname{sod} A$, one cannot rule out the possibility of Arc or Fnr modulating an independent effector molecule in response to either signals of respiratory or oxidative environment.

We are grateful to R. P. Gunsalus and E. C. C. Linn for providing strains and/or plasmids that were used in this study, and to $S$. Bowen for allowing us to use his sequence data before publication. This work was supported in part by DCB8910153 from the National Science Foundation. M.D.B. is a recipient of a USDA National Needs predoctoral traineeship.

\section{References}

BACHMANN, B. J. (1990). Linkage map of Escherichia coli K12, edition 8. Microbiological Reviews 54, 130-197.

BAGG, A. \& NeIlandS, J. B. (1987). Ferric uptake regulation protein acts as a repressor, employing iron(II) as a cofactor to bind the operator of an iron transport operon in Escherichia coli. Biochemistry 26, 5471-5477.

Beauchamp, C. O. \& Fridovich, I. (1971). Superoxide dismutase: improved assays and an assay applicable to acrylamide gels. Analytical Biochemistry 44, 276-287. 
Beaumont, M. \& Hassan, H. M. (1990). Role of fur regulon on the expression of sodA in Escherichia coli. Abstr. H-114, p. 173, Abstr. 90th Annual Meeting, American Society for Microbiology.

Beaumont, M. \& Hassan, H. M. (1991). Characterization of a $\operatorname{sodA}$ mutant of Escherichia coli: regulatory role of Arc and Fur. FASEB Journal (Abstract) 5, 2586.

Beaumont, M. \& Hassan, H. M. (1992). Characterization of a sodA mutant of Escherichia coli. Current Microbiology 25, 135-141.

COMPAN, I. \& TOUATI, D. (1993). Interaction of six global transcription regulators in expression of manganese superoxide dismutase in Escherichia coli K12. Journal of Bacteriology 175, 1687-1696.

GARDNER, P. \& FRIDOVICH, I. (1987). Controls on the biosynthesis of the manganese-containing superoxide dismutase of Escherichia coli. Journal of Biological Chemistry 262, 17591-17595.

Greenberg, J. T., Monach, P. A., Chou, J.-H., Josephy, P. D. \& Demple, B. (1990). Positive control of a global antioxidant defense regulon activated by superoxide-generating agents in Escherichia coli. Proceedings of the National Academy of Sciences of the United States of America 87, 6181-6185.

GREGORY, E. M. \& FRIDOVICH, I. (1973). The induction of superoxide dismutase by molecular oxygen. Journal of Bacteriology 114, 543-548.

Hanson, R. S. \& Phillips, J. A. (1981). Chemical composition. In Manual of Methods for General Bacteriology, p. 355. Washington, DC: American Society for Microbiology.

Hassan, H. M. (1989). Microbial superoxide dismutases. Advances in Genetics 26, 65-97.

Hassan, H. M. \& Fridovich, I. (1977). Regulation of the synthesis of superoxide dismutase in Escherichia coli: induction by methyl viologen. Journal of Biological Chemistry 252, 7667-7672.

Hassan, H. M. \& Fridovich, I. (1979). Intracellular production of superoxide radical and of hydrogen peroxide by redox active compounds. Archives of Biochemistry and Biophysics 196, 385-395.

HASSAN, H. M. \& MoODY, C. S. (1984). Induction of the manganesecontaining superoxide dismutase in Escherichia coli by nalidixic acid and iron chelators. FEMS Microbioloty Letters 25, 233-236.

Hassan, H. M. \& Sun, H. C. H. (1991). Regulatory role of Fnr in the expression of Mn-superoxide dismutase in Escherichia coli. FASEB Journal (Abstract) 5, 2585.

Hassan, H. M. \& Sun, H. C. H. (1992). Regulatory roles of Fnr, Fur and Arc in the expression of the manganese containing superoxide dismutase in Escherichia coli. Proceedings of the National Academy of Sciences of the United States of America 89, 3217-3221.

IUChi, S., Cameron, D. \& Lin, E. C. C. (1989). A second global regulator gene $(\operatorname{arcB})$ mediates repression of enzymes in aerobic pathways of Escherichia coli. Journal of Bacteriology 171, 868-873.

JONES, H. M. \& Gunsalus, R. P. (1987). Regulation of Escherichia coli fumarate reductase operon expression by respiratory electron acceptors and the fnr gene product. Journal of Bacteriology 169, $3340-3349$.

KILEY, P. J. \& ReZNIKoFF, W. S. (1991). Fnr mutants that activate gene expression in the presence of oxygen. Journal of Bacteriology 173, 16-22.

MCCORD, J. \& Fridovich, I. (1969). Superoxide dismutase: an enzymatic function for erythrocuprein (hemocuprein). Journal of Biological Chemistry 244, 6049-6055.

Miller, J. (1972). Experiments in Molecular Genetics. Cold Spring Harbor, NY: Cold Spring Harbor Laboratory.

Moody, C. S. \& Hassan, H. M. (1984). Anaerobic biosynthesis of the manganese-containing superoxide dismutase in Escherichia coli. Journal of Biological Chemistry 259, 12821-12825.

NaIK, S. \& Hassan, H. M. (1990). Use of site directed mutagenesis to identify an upstream regulatory sequence of $\operatorname{sodA}$ gene of Escherichia coli K12. Proceedings of the National Academy of Sciences of the United States of America 87, 2618-2622.

NeIDERHOFFer, E., NARANJo, C. \& FeE, J. (1989). Relationship of the superoxide dismutase genes ( $\operatorname{sod} A$ and $\operatorname{sod} B)$ to the iron uptake (fur) in Escherichia coli K12. UCLA Symposium on Molecular and Cellular Biology 98, 149-158.

Neiderhoffer, E., NARANJo, C., Bradley, K. \& Fee, J. (1990). Control of Escherichia coli superoxide dismutase ( $\operatorname{sod} A$ and $\operatorname{sod} B)$ genes by the ferric uptake regulation (fur) locus. Journal of Bacteriology 172, 1930-1938.

PresutTI, D. G. (1992). Identification of sodA sequence-specific binding proteins in Escherichia coli, abstr. H-310, p. 234. Abstr. 92nd Annual Meeting, American Society for Microbiology.

Privalle, C., BeYer, W. F. \& Fridovich, I. (1989). Anaerobic induction of ProMn-superoxide dismutase in Escherichia coli. Journal of Biological Chemistry 264, 2758-2763.

PUGH, S. \& FRIDOVICH, I. (1985). Induction of superoxide dismutases in Escherichia coli B by metal chelators. Journal of Bacteriology 162, 196-202.

SAMBroOK, J., FritsCh, E. \& MANIATIS, T. (1989). Molecular Cloning: A Laboratory Manual, 2nd edn. Cold Spring Harbor, NY: Cold Spring Harbor Laboratory.

SANGer, F., Nicklen, S. \& Coulsen, A. R. (1977). DNA sequencing with chain terminating inhibitors. Proceedings of the National Academy of Sciences of the United States of America 74, 5463-5467.

SAWERS, G. \& SUPPMANN, B. (1992). Anaerobic induction of pyruvate formate-lyase gene expression is mediated by the ArcA and Fnr proteins. Journal of Bacteriology 174, 3474-3478.

Schiavone, J. R. \& Hassan, H. M. (1988). The role of redox in the regulation of manganese-containing superoxide dismutase biosynthesis in Escherichia coli. Journal of Biological Chemistry 263, $4269-4273$.

SCHRUM, L. W. \& Hassan, H. M. (1990). Role of DNA topology in the expression of the sodA gene in Escherichia coli using operon fusion. Abstract H-73, p. 166, Abstr. 90th Annual Meeting, American Society for Microbiology.

SCHRUM, L. W. \& HASSAN, H. M. (1992). Transcriptional regulation of Mn-superoxide dismutase gene $(\operatorname{sod} A)$ of Escherichia coli is stimulated by DNA gyrase inhibitors. Archives of Biochemistry and Biophysics 299, 185-192.

Singer, M., Baker, T., Schnitzler, G., Deischel, S., Goel, M., Dove, W., JaAcks, K., Grossman, A., Erickson, J. \& Gross, C. (1989). A collection of strains containing genetically linked alternating antibiotic resistance elements for genetic mapping of Escherichia coli. Microbiological Reviews 53, 1-24.

Shaw, S. \& Guest, J. R. (1982). Nucleotide sequence of the fnr gene and primary structure of the Fnr protein of Escherichia coli. Nucleic Acids Research 10, 6119-6130.

SPIRO, S. \& GUEST, J. R. (1990). Fnr and its role in oxygen regulated gene expression in Escherichia coli. FEMS Microbiology Reviews 75, $399-428$.

TAKEDA, Y. \& Avila, H. (1986). Structure and gene expression of the Escherichia coli manganese superoxide dismutase gene. Nucleic Acids Research 14, 4577-4589.

TARDAT, B. \& TuOATI, D. (1991). Two global regulators repress the anaerobic expression of MnSOD in E. coli: Fur (ferric uptake regulation) and Arc (aerobic respiratory control). Molecular Microbiology 5, 455-466.

TounTI, D. (1983). Cloning and mapping of the manganese superoxide gene (sodA) of Escherichia coli K12. Journal of Bacteriology 155, 1078-1087.

TOUATI, D. (1988). Transcriptional and post-transcriptional regulation of manganese superoxide dismutase biosynthesis in Escherichia coli studied with operon and protein fusions. Journal of Bacteriology 170, 2511-2520.

Trageser, M., Spiro, S., Duchene, A., KoJro, E., Fahrenholz, F., GUEST, J. R. \& UNDEN, G. (1990). Isolation of intact Fnr protein of Escherichia coli. Molecular Microbiology 4, 21-27.

TSANEVA, I. \& WEISS, B. (1990). sox $R$, a locus governing a superoxide response in Escherichia coli K12. Journal of Bacteriology 172, $4197-4205$.

UNDEN, G. \& Trageser, M. (1991). Oxygen regulated gene expression in Escherichia coli: control of anaerobic respiration by the Fnr protein. Antonie van Leeuwenhoek 59, 65-76. 